\title{
Immersive fantasy writing using role playing and augmented reality apps
}

\author{
Cathy Oxley \\ (With special thanks to Anne Weaver, Melinda Egan and Sue Miles) \\ Brisbane Grammar School \\ Gregory Terrace, Brisbane 4000 \\ Australia \\ cathy.oxley@brisbanegrammar.com
}

\begin{abstract}
Collaborative writing has been shown to improve students' writing enjoyment, and to improve writing outcomes for some students. Building on past experiences with collaborative writing workshops, the teacher-librarians from four schools decided to change the focus of the workshop this year to a fantasy writing workshop. To simulate the challenges of a hero's quest, immersive role playing activities, team-building and problem-solving games and the use virtual and augmented reality apps were introduced. This paper investigates experiential learning as a means by which teacherlibrarians can add value to their school's curriculum and learning outcomes. It looks at ideas from other educators which were incorporated into the workshop, the challenges and successes of the workshop, and feedback given by the students.
\end{abstract}

Keywords: Collaborative writing, Fantasy writing workshop, Immersive role-playing, Team-building games, Augmented reality apps.

\section{Introduction}

For three years the teacher-librarians from four neighboring schools had developed and refined a creative writing workshop, the Spring Hill Young Writers (SHYW) Workshop, exploring ways of enhancing creative writing with an author in a collaborative setting. Evidence-based practice involved monitoring student involvement and engagement, and seeking feedback from them and the author through the use of survey tools. This allowed improvements to be made each year.

In 2015 the idea of incorporating gamification and a shared online adventure quest was explored. One of the teacher-librarians undertook a significant amount of research into various role based games and online fantasy games, and some of her research can be seen here: https://readingpower.wordpress.com/2014/12/15/draft-immersive-fantasy-writing-quest/ Students and colleagues were asked for suggestions of multi-player role-playing games which might be useful for the workshop. Those suggested by students were either too young and unappealing, too violent and not G / PG rated or did not involve a band of avatars working together to survive a malevolent force. Other concerns with online games were: how long it would take to learn them, the difficulty of organizing all students in a group to be online together, difficulties with setting up the groups to meet each other in the time frame, 
problems with parental consent and concerns over possible gaming addiction. In the end, online gaming was rejected as an unsuitable option.

Based on research and ideas from other teachers using experiential learning activities and augmented reality apps, planning took a new direction when it was decided to develop a series of physical and sensory challenges and immersive role-playing to provide a more authentic base from which to write. The aim of this workshop then became an investigation into whether simulating some aspects of a fantasy quest would improve student writing. By using augmented reality apps, game theory, sensory activities, various mobile technologies and collaborative team challenges, it was hoped that students' imaginations would fill in the gaps - that the Roma Street Parklands really would become the Land of Remorse, a land where dragons, monsters and fearsome spiders lurked along with an abandoned castle, where quicksand and minefields could trap unwary heroes, where armour and weapons needed to be chosen carefully, and where guessing the answers to riddles could mean the difference between life and death.

\section{Overview of the Workshop}

Four teacher-librarians from two girls' schools and two boys' schools each selected eight Year 8 students to participate in this creative fantasy-writing workshop. The intention was to utilise the Roma Street Parklands adjacent to the street on which three of the schools are located, and eight activity stations were planned for the students to rotate around in groups of four. A map of the 'Land of Remorse' was drawn up, which included each of the activities stations: the Armoury, the Field of Doom, the Stone Table, the Epic Citadel, the Cursed Quicksand, the Fiendish Forest, the Eerie Escarpment and the Tunnel of Terror. Each activity would focus on a different sensation - touch, smell, hearing, sight - as well as incorporating different augmented and virtual reality iPad apps at as many of the activity stations as applicable. Local fantasy author, Kirilee Barker, was invited to participate as the Supreme Sorceress. In costume on each of the days, she gave instructions, helped with challenges and taught creative writing skills.

On the first afternoon the students were allocated a team, with one student from each school in each team. Each student chose a special character strength from the Choosing Bowl, which they then were expected to incorporate into their story. They were given writing journals and a coloured bandana to denote their team. Team names were taken from fantasy stories: Hermione, Aslan, Atreyu, Eragon, Dumbledore, Gandalf, Excalibur and Artemis. Team problem-solving games were played as ice-breakers.

The following day each team completed a number of physical role-playing and team-building challenges on their quest to free their village from a monstrous evil. (See Table 1) At each challenge they were also given time to write about their feelings, reactions and teamwork issues as they developed their setting, characters and storyline. (See Table 2) A number of augmented reality apps on iPads were incorporated into the activities: Aurasma was used for accessing riddle clues; Anomaly was used in conjunction with the Anomaly book (http://www.experienceanomaly.com/anomaly) for viewing monsters and battles; Dragons! enabled students to see fire-breathing dragons flying above them; and Real Scary Spiders allowed students to make huge virtual spiders crawl over their team members. For developing the setting the virtual castle app, Epic Citadel, was used. These activities were meant to be held in the Roma Street Parklands, the 'Land of Remorse' but, due to heavy rain, they had to be relocated to the All Hallows Library instead. While this was disappointing and not the original intention, it did show that a parklands was not necessary for the activities to occur. 
On the third day of the workshop the students worked with the author to structure their ideas and to craft them into a short story. Some time was allowed for the students to work together as a group to plan their shared story structure and setting. A wiki was set up so that the author, teacher-librarians and students in each group could share common ideas, communicate with each other and read each other's stories. Students were given a further opportunity one afternoon to meet face-to-face, plan, write and edit and, on a final presentation afternoon, the author awarded prizes for the best individual and group stories. Participating in this creative writing workshop provided an authentic experience to enrich students' writing and also deepened their understanding of the complex physical and emotional factors involved in the hero's quest.

\section{Inquiry Questions}

- Would the inclusion of experiential learning - physical and sensory activities focusing on touch, taste, smell, sight and hearing - improve students' writing by making this a more authentic experience?

- Would the inclusion of team-building and problem-solving games help students to become more cohesive in their groups?

- Would changing the focus of the workshop from creative writing to a fantasy hero's quest engage the students more and further improve their writing?

- Would it be better to have fewer in-depth activities and to allocate longer time to each?

\section{Significant Influences}

Five factors influenced the development of the 2015 SHYW workshop in its current format:

- Past SHYW workshops

From a shared interest in the ability of collaborative writing to improve students' engagement and writing, the Spring Hill Young Writers workshop was born. This involved eight Year 8 students each from two inner city boys' schools and two inner city girls' schools. Joined by a road called Boundary Street the motto, aptly, was 'Pushing the Boundaries.' The initial three years of the workshop involved 32 students working together in groups of four (one from each school) to create and write a shared story with the same four characters, the same plot and the same setting, but with each story told from a different character's point of view. Author, Brian Falkner, worked with the group for these three years, and developed a valuable rapport with the students across the 4 days where he was involved with them. (Information from these workshops can be found here: http://www.slideshare.net/ASLAonline/collaborative-writing-9583106)

\section{- Year 8 Fantasy Adventure Writing Camp} In 2013, Lyndell Sellars and Peter MacGregor won the Queensland School Library Association's Brian Bahnisch Award for their innovative Year 8 Fantasy Adventure Writing Camp, a joint initiative of Malanda SHS and Tinaroo Environmental Education Centre:

"Our aim is to create a fantasy setting on the banks of the Lake of Mirrors and to stage a quest designed to inspire young creative writers. Integration of outdoor experiences and physical challenges (canoeing, hiking, raft building, high ropes) with iPad technology and explicit teaching of writing techniques 
result in an enriched learning experience to extend students with a passion for writing. The writing process is further enhanced by a creative writing workshop hosted by a guest fantasy author, (Karen Healey 2011 and Michael Pryor 2012, 2013 and 2014). The culmination of the program is the student presentation of a piece of writing inspired by their experience."

(https://tinarooeec.eq.edu.au/Programsandactivities/Ourprogramsandactivities/Pages/ Year-8-Fantasy-Writers-Camp.aspx)

Based on the success of their work, it was decided to add in an extra physical roleplaying dimension to the SHYW workshop, hypothesizing that this would encourage the students to write even more creatively. The four teacher-librarians met each week for 10 weeks, planning and developing each of the eight activities to be included. These were to replace the writing day normally held on the second day of the workshop; however, writing was still planned for that day and the students were given journals with prompt questions and space for notes at each activity.

- Band of Heroes Fantasy Blog

In 2012 Elizabeth Chase, working for the NSW Department of Education and Training, developed the Band of Heroes fantasy writing activites, a five week unit which became a source of inspiration and helped to shape the SHYW 2015 workshop.

- Elizabeth's Band of Heroes are:

- Complex: "The problems faced by the heroes are complex. The real world backdrop may be implied, not stated: Environmental, social, political, personal, class and economic issues compete for human attention in the $21 \mathrm{C}$.

- Collaborative: The problems require a group solution.

- Contextual: The place, people and problems are specific, not universal. eg The place is conjured up with great care and is very evocative.

- Champions: Different heroes come into focus in different episodes/chapters. Point of view is critical to conveying their journeys. The heroes are flawed and have specific strengths - in combination the band of heroes is strong. The heroes are often home town. Sometimes, they share characteristics with the outsider hero - there is not a complete disjunction."

- Their mission, over 10 levels, is to save a magical world from evil:

Level 1 - Pulled to a new world

Level 2 - New world setting

Level 3 - Meet the band \& wise one explains quest

Level 4 - Magical strength

Level 5 - Weapon \& band plans a group attack on the evil ruler

Level 6 - Individual battle with evil minion

Level 7 - Magical helper activates magical strength

Level 8 - Battle scene, combined strengths of band, evil ruler destroyed

Level 9 - Quest object gained, celebrations in kingdom, new ruler chosen

Level 10 - Farewell by band members, return home or stay

Read more at: http://www.band-of-heroes.net/band/ 
- Tim Ryland's work with the iPad app Epic Citadel

Tim Ryland is an extremely gifted and inspirational teacher, who encourages literacy and creative writing through the activities he helps teachers to develop with online games. $\mathrm{He}$ is known for his use of the Myst series of games to promote literacy and inspire creativity; he has also helped to design creative writing units of work using the app Epic Citadel.

Tim comments:

"I've always coupled this work on King Arthur and the Knights of the Round Table. I'm sure the chronology doesn't match entirely but it works well regardless!

Recently I coupled this with Myst and a few other games-based learning activities over a 5 months period. I also took some baseline and summative data on attainment and attitudes towards writing. My plan was to see if I could get the boys in $Y 6$ to radically improve both of these. It worked. Hugely."

(Read more at: http://www.gamesrichclassroom.blogspot.co.uk/2014/04/epic-resultswith-citadel-planning.html)

\section{- Augmented Libraries Teacher Librarian Network Day}

Attendance by some of the SHYW teacher-librarians at an Augmented Reality workshop was instrumental in the investigation of many different free augmented reality apps and the subsequent inclusion of some of them in the workshop activities. Those included were Aurasma, Real Scary Spiders, Dragons! and Anomaly.

\section{Analysis and Reflections}

\section{Problems with the 2015 SHYW workshop}

- Rain - Due to torrential rain in the early morning, the Land of Remorse activities had to be relocated to a school library. At first some students didn't know where they were going as the map had to be re-drawn to suit the library; some activities were not in the same sequence. There was some confusion early in the day as one group stayed in the same activity for an hour instead of moving on after $1 / 2$ hour. This meant they then had to catch up at lunch time.

- The journals were given out on the first afternoon but then collected again in case the students forgot to bring them the following morning. In retrospect this was a mistake, as the students did not have a chance to read through the journals when they were enthusiastic and had time. In the confusion and disappointment of the relocation the following morning, there wasn't time for the students to look in detail at their journals. Some activities were so involved that there was not enough time left for completing their journal entries.

- Some activities were perceived by some students as inferior to others. Student feedback:

○ "I'd like less technology like the spiders and epic citadel that really didn't help our writing."

- "The tunnel of terror was, personally, quite pointless and didn't help."

- "Some of the activities such as tunnel of terror, cursed quicksand, field of doom weren't as effective as they weren't as relevant." 
- Maybe the library assistants hadn't been prepared properly about the need for metacognition related to experiential learning and didn't give as much time as the teacher-librarians did to making the students reflect on how each activity could be incorporated into their stories. Student feedback:

- "The contemplation and discussion sessions were very good."

- "More analysing - which character would be strongest to defend against this obstacle and which character strengths would be most useful."

- There was not as much time for students to write together. Maybe the students should have stayed on after the physical activities were finished to go through their journals together, answering all of the questions and making notes, talking to their group members and beginning to plan their group story.

- On the writing day, the author had prepared four very helpful writing activity sessions with ideas for developing characters, storyline, setting and descriptive writing. However the students were very keen to write their own stories and they only had two hours or less after lunch to do this. There was a noticeable drop in input on the wiki pages compared to the last time this workshop was run. Group homepages were generally better than individual pages, maybe because this was modelled. Student feedback:

- 12 out of 21 students said they would like more time on the third day to plan with their groups and write their stories.

- There were too many writing activity sessions one after the other. In the past these were spread out at the beginning of each session over two writing days and then the students had time to write. Possibly next time the author could give an activity about setting or descriptive writing, then give the students time to write in their own journals/ on the wiki after this. Group planning time on the second afternoon would also have helped.

\section{Experiential Learning Activities - did they help?}

Definitions:

"Experiential learning is authentic, first-hand, sensory-based learning. Experiential activities explore, touch, listen to, watch, move things, dissemble and reassemble. Learning consists of grasping an experience and then transforming it into an application or result." (Kolb, 1983, quoted in ).

"In its simplest form, experiential learning means learning from experience or learning by doing. Experiential education first immerses learners in an experience and then encourages reflection about the experience to develop new skills, new attitudes, or new ways of thinking." (Lewis and Williams 1994, p.5, quoted in Schwartz) (http://www.ryerson.ca/content/dam/lt/resources/handouts/ExperientialLearningReport. pdf)

One of the aims of the workshop was to investigate whether the experiential learning activities would be transferred into the students' own stories. This was never stated as a requirement; the students could set their fantasy story in any location or time period. 
However, many of them chose to incorporate aspects of their quest in the Land of Remorse into their stories.

By far the favourite activity was the Armoury, where the students were able to try on armour and practice jousting and javelin throwing. 16 out of 31 students mentioned the Armoury in their feedback and how much they enjoyed it. Student feedback:

- "I liked the armoury because it was immersive and really helped character development. It gave me a great feeling on how the weapons and armour would feel and which would suit my character the most."

- "I think the armoury will help me with my writing because it will help me understand the preparations needed for a quest."

There were many other favourable comments about the activities. Student feedback:

- "The stone table is a pivotal moment in the story."

- "The Epic Citadel will be our Sorcery Academy."

- "The activity contained writing a paragraph about dragons and this is an idea that can be put into any story."

- "I think it helped me get in the mood and see how my character could escape from danger and how she could help her group."

It was also satisfying to see that some students appreciated the teamwork games. Student feedback:

- "It showed the importance of teamwork and communication while enjoying a fun challenge."

- It will help me to understand better how to write about working as a team.

- "I liked it because we got to work well as a team."

- "I really enjoyed it as it was great fun to have your partner as your 'eyes'. It was fun to put your complete trust in your partner so that you could survive the challenge."

- "I think the Cursed Quicksand will help the most as I will be able to write about the teamwork involved, and I will be able to write about the growing fear as each lilypad was lost."

Most groups used some aspects of the activities and locations in their shared story details on their wiki homepages:

Group 1 Dumbledore

Characters and Traits:

Determined- Carlos

Humble-Mattias

Wise- Evanlyn

Enthusiastic- Grace

"We might like go into a maze where one of us is blindfolded or we have had a potion that makes us blind for like the entire maze, then we might come across a cross road where a stone table is set with all these riddles."

Group 2 Excalibur

- 'Sorcery school finds out its students' elemental powers, looking for the four who have the powers of fire, water, air and earth to go on a quest 
- 4 main characters are found to possess these elemental powers and are chosen for the quest to the Land of Remorse

- They go into forest and encounter Nixies (evil faeries)

- Nixies try to lure them into a trap

- They refuse and start to walk away

- Nixies begin chase

- They encounter a swamp and quickly cross over via magical lily pads

- They manage to escape forest and continue onto their next obstacle"

\section{Group 3 Gandalf}

- "Amity, Eldrid and Maple meet at swamp

- We get through the swamp and meet Sly

- We find a note addressed to us saying we have to get to the Epic Citadel via the Stone Table (I'm not sure why we follow what the letter's saying but sure)

- We go to the Stone Table and figure out the riddles

- Xander falls unconscious (we think he's dead) and Amity goes blind as a result of the poison

- Amity keeps seeing a weird dark angel even though she's blind

- We carry on to the Fields of Doom where Eldrid and Maple have to tell Amity where to go

- Finally, we get to the Epic Citadel where we meet Xander who is actually alive *gasp* and tells us we've walked into a trap (set by the weird dark angel) *gassssppp*

- He also has a dragon :3

- Amity disappears looking for the angel and is suddenly not blind *small crowd of children cheering ${ }^{*}$ by finding an antidote for the poison she drank

- The angel ambushes us and tries to kill us but we use our awesome powers and our dragon to defeat it

- The people who abandoned the citadel are so grateful they make us general rulers

Weapons

- Maple Hartley - Longsword and shield

- Amity Irons - short sword

- Eldrid Lymp - dual tomahawk"

- Sly - dagger

\section{Group 4 Aslan}

"Lionel: character strength - risk taker

I barreled through the wreckage of a wagon and up constricting alleyways, dodged around a labyrinth of streets and ducked into a dimly lit avenue. Pausing for breath, I twisted as I heard the sound of pursuit on the densely packed cobblestone. Two girls barreled around the corner, eyes rapidly widening as they focused on my silhouetted figure, flickering in the red light of the flames in my palm. I didn't blame them. I was tall and well build, with arms hardened and strengthened by the hours of sword fighting."

\section{Group 5 Atreyu}


"Meet at the funeral, find a portal, takes us to the epic citadel, we find the armoury, we escape, we travel through the fiendish forest to get to the evil guy (WHAT IS IT) and we have to get past the stone table, and then we defeat the evil guy. (WHO IS THE EVIL GUY?)

The setting is Earth first and then Land of Remorse.

They arrive at the Citadel and locate an armory. Here the local blacksmith makes weapons for them. The blacksmith also tells them that dragons have been sighted in caves in the middle of the fiendish forest.

We travel through the Fiendish Forest. During our time there we come across challenges such as: Spiders, Barbarians. Finally we reach the cave. And battle with the dragon. We kill it and take the tooth."

Group 5 also included their character strengths in their story:

"Four children: Jono, Edmund, Emma, Libby. They are offspring to 4 senior officers in a secret Order. From birth they have been raised to one day step into the place of their parents. Being descendants of the Secret Order, they were born with special powers; Endurance, Honesty, Persuasion, Intelligence. One day, their parents tell them that they need to create a magic potion, and they have all the ingredients except for a dragons tooth. The potion is supposedly to heal the head of the organisation, Ezra Ordure."

\section{Group 7 Hermione}

- "Citadel of Malevolence and Agony Keep

- Sinister Swamp/ Cursed Quicksand

- Fiendish Forest

- Blazing Battlefield (Against the Evil Creature)

"The story is set in the vast world of Alanguish. The world includes many castles and strongholds, as well as mystical areas. These include the steel tower, stone fort, castle paladin, citadel of malevolence, and agony keep. These are occupied not only by the good forces of Alanguish, such as the iron heart paladins and the rangers of gold, but also the forces of evil such as the dark archers of agony keep and the lancers of doom."

\section{Group 8 Artemis}

"Tristan - Fights with a hand axe and rounded shield, with a Kukri knife sheathed on his belt. All the blades are Damascus Steel. His shield bash can send enemies flying, and a strike from the edge of his shield will break the nose and teeth of anyone in his way."

\section{Conclusion}

As part of the deconstruction process for this workshop, it's always interesting to reflect on how much more could be achieved if there was a longer period of time allocated for the workshop.

Three of the significant factors which shaped the 2015 SHYW workshop took place over a much longer time period:

- Year 8 Fantasy Adventure Writing Camp - 1 week

- Band of Heroes Quest - 5 weeks 


\section{- Tim Rylands' unit using Epic Citadel - 5 months}

It would be interesting to gain student feedback on whether they thought it would be more useful to reduce the number of activities but to spend more time on each. Having one group begin at each of the activity stations and then rotate each half hour was exciting and engaging for the students, but did not always allow time to tap into ideas that shape learning and lead to mature story-writing - e.g. which of the heroes in the group would dominate or struggle at each activity, due to their character strengths and weaknesses? Would the characters admit that a particular challenge might make them feel confronted or fearful? Would the characters find it difficult to get along with everyone in the group, particularly if they had strong personality traits?

Overall, however, there were many successful elements in the workshop this year, some of which were sourced from other teachers. While the ideas from Lyndell Sellars and Peter MacGregor gave an insight into the potential of immersive experiential activities to promote creative writing, there was never an intention to copy exactly what they had done. The SHYW workshop has always entailed students working in groups of four, developing a shared plot, setting and characters, and then writing the story from the perspective of one of those characters. Similarly, while the Band of Heroes activities gave excellent guidance for developing a hero's quest, this activity was purely online and did not suit the needs of the SHYW workshop. Tim Ryland's work with Myst and Epic Citadel was influential in the development of the Epic Citadel activity and the word walls in the student journals, but this activity was just one of eight half hour sessions, rather than a ten week unit. However all of these ideas had an important influence on shaping the direction of this year's workshop. The added dimension to the workshop of a physical quest with a group of fellow travellers (albeit strangers) was a very engaging strategy, particularly for boys who love to be moving and physically active. Being able to move between activities and to physically hold items or solve problems as a group was a successful bonding and unifying experience. Having to rely on your team-mate while blindfolded was also highly effective in teaching the value of accurate communication. The getting-to-know you activities that the author brought to the first afternoon were a very effective fun way of making the students interact and appreciate the value of communication - e.g. untangling a human knot. The Supreme Sorceress dressed in costume over the course of the workshop helped to cement the fantasy setting and time period for the students.

While each activity was excellent and highly worthy in its own right, some were considered by the students as inferior simply because of the strength of competing activities in the quest. It was like offering the students Disneyland and asking them to compare attractions. The addition of a whole day of physical activities meant that there was far less time than in the past for sitting and writing. While each activity station was meant to allow time for writing in the student's journals, some stations had lengthy activities and so the students did not have time to write. Some of the activity supervisors did not encourage group reflection and journal writing. The journals very clearly stated that students were to write about their emotions and feelings at each of the activities. However there was not much evidence of this in their stories. Maybe they thought it was irrelevant, or maybe they did not realise this was an important aspect of character development.

Including the augmented reality (AR) apps added a dimension which would not have been possible in earlier years. While the teacher librarians thought these were very engaging, many of the students had smart phones with them and effortlessly used these as well as the iPads to engage in the AR activities. Some students strategized and worked out that they 
could scan the AR images in their journals ahead of each station to collect the magical power prize first. Their ability to navigate games quickly and easily was also underestimated. Some finished exploring the castle and controlling the spiders very quickly and were keen to move on immediately to the next activity; they were impatient when made to stay and discuss and write in their journals. Being used to highly detailed and interactive computer games, some found the AR apps a little boring.

While there was no doubt that the students were learning, focused, engaged and having fun, the pivotal question remained: Was there enough depth in each activity for them to assimilate the experiences into their own writing? While the students loved the activities, did we capitalise on this for their learning? Did they write any differently to how they had previously? Student comments say it all: "It gave us a world to explore and really got me thinking about possible stories and explanations and how best to describe them." "I liked it because it was extremely realistic."

Just another example of libraries making learning real.

\section{References}

Behrendt, M. \& Franklin, T. (2014). A Review of Research on School Field Trips and Their Value in Education. International Journal of Environmental \& Science Education, 6(3), 235-245. doi:10.12973/ijese.2014.213a

Schwartz, M. (n.d.). Best Practices in Experiential Learning. The Learning and Teaching Office. Retrieved from http://www.ryerson.ca/content/dam/lt/resources/handouts/ExperientialLearningRep ort.pdf

Additional Resources

Activities for the Year 8 Fantasy Adventure Writing Camp by Lyndall Sellars and Peter MacGregor https://tinarooeec.eq.edu.au/Programsandactivities/Ourprogramsandactivities/Pag es/Year-8-Fantasy-Writers-Camp.aspx

Activities for the Band of Heroes unit

http://rapblog15.edublogs.org/

http://www.band-of-heroes.net/band/

http://bandofheroes.weebly.com/

http://www.readwritethink.org/files/resources/interactives/herosjourney/heros journey.html http://www.schools.nsw.edu.au/raps/twist13/twist13pdf/Bandofheroes TaskWorksheets.pdf http://www.schools.nsw.edu.au/raps/twist13/twist13pdf/Bandof\%20heroes SamplelmageCar ds.pdf http://www.schools.nsw.edu.au/raps/twist13/twist13pdf/Bandofheroes ImageCardTasks.pdf https://online.det.nsw.edu.au/blog/258571-fantasyfanfiction/entry/band of heroes incursion https://onedrive.live.com/view.aspx?cid=985D506652839C93\&resid=985d506652839c93\%2 $1743 \& q \mathrm{t}=$ sharedby\&app=PowerPoint\&authkey=\%21 AEm2IKPZBWQi-Mg http://bandofheroes.weebly.com/blog http://www.mixbook.com/photo-books/interests/campground-adventures8963841 ? vk=mK4wXkUjgU

Activities from Tim Rylands' units using Myst and Epic Citadel 
Tims' story of The Pickpocket, recorded over images from Epic Citadel. http://www.porchester.notts.sch.uk/citadel/2010/10/the-pickpocket.html Youtube clip of Tim encouraging creative writing with Myst Exile https://www.youtube.com/watch?v=X5xFMmK5Ujs

Other Myst teaching ides

http://www.teachingideas.co.uk/themes/myst/

Example of use of Epic Citadel in the classroom - Digital Teacher

http://www.digital-teacher.co.uk/2010/11/an-epic-project-draws-to-its-end.html

Porchester School's activities using Epic Citadel

http://www.porchester.notts.sch.uk/citadel/animoto/

Previous SHYW workshop details

http://www.slideshare.net/ASLAonline/collaborative-writing-9583106)

\section{Biographical Note}

Cathy Oxley has worked as a teacher librarian for 30 years in both primary and secondary schools, and loves empowering students with Web 2.0 tools to enable rich, collaborative learning experiences for both research and reading. Since 2009 she has been Director of Information Services at Brisbane Grammar School, a large day and boarding school with 1700 boys in Years 5 to 12. She is currently President of the Brisbane School Library Association. 


\section{Appendix I}

DAY 1 - MEET THE AUTHOR AND LEARN ABOUT THE QUEST

Tuesday 31 March 3.30 - 5.30pm at Brisbane Girls Grammar School

Author, Kirilee Barker, author of The Book of Days, will meet with the 8 students from each school (BGS, BGGS, All Hallows, Terrace).

The quest and workshop will be explained and journals given out.

Students will be divided into teams of four, with one from each school in each group. (Group names: Hermione, Aslan, Atreyu, Eragon, Dumbledore, Gandalf, Excalibur, Artemis) Coloured bandanas will be given to denote team members.

Students will be allocated a special character strength that will help them to complete their quest.

Kirilee will be the Supreme Sorceress - Students will choose their character strengths from a Choosing Bowl.

Individual character and physical strengths will be written on a badge which students wear so that others in their group know their powers.

For homework, students will develop their Character Profiles in their journals.

DAY 2 - FANTASY WRITING QUEST ACTIVITIES

Wednesday 1 April 9.00am - 2.45pm in the Roma St Parklands

Activity stations - each group of 4 begins at a different station, then they rotate clockwise, using the map.

A staff member will supervise each station.

At each activity, students in a group of 4 scan a QR or Aurasma code to collect information or part of a riddle.

Students will rotate around different physical activities and solve the puzzle/ riddles

Students will be involved in teamwork activities (selected from school Physical Education programs) and problem solving with other

characters on the quest

At each activity, students will have time to write about the challenges, their teamwork and their emotions to assist writing a story in

first person. Students will develop a rich list of adjectives, nouns, verbs, sentences, imagery and phrases.

DAY 3 - FANTASY WRITING WORKSHOP

Thursday 2 April 9.00am - 2.45pm at Brisbane Grammar School

Kirilee Barker will work all day with the students to take their notes and thoughts from the previous day's immersive challenges and construct them into a first person fantasy narrative. She will help them to develop their characters and add depth and flair to their storytelling.

Students will transfer their notes and stories to the wiki so everyone has access to them. Peer feedback will be given via the comments section of the wiki.

Students will complete a survey about the experience and whether or not they think it has helped their creative writing process.

DAY 4 - FANTASY WRITING AFTERNOON

Thursday 23 April 3.30-5.30pm at Brisbane Grammar School

Students will meet again with their other team members to further refine the details of their quest and continue editing their stories.

DAY 5 - FINAL PRESENTATION AFTERNOON

Thursday 14 May $3.30-5.30 p m$ at BGGS

The author will present awards for the best individual and group stories, and students will give their reflections of the experience.

Table 1: Activities for Each Day of the Workshop 


\section{Appendix II}

\begin{tabular}{|c|c|c|c|}
\hline $\begin{array}{l}\text { LOCATION } \\
\text { AT ROMA ST } \\
\text { GARDENS }\end{array}$ & DESCRIPTION & JOURNAL ENTRY & STORY \\
\hline $\begin{array}{l}\text { 1. } \\
\text { Armoury } \\
\text { (Gazebo) }\end{array}$ & $\begin{array}{l}\text { Try on armour - chain-mail helmet, sword, fur cloak, } \\
\text { velvet dress, leather boots, linen clothes. Choose the } \\
\text { special weapon your character will use. Carry a } 20 \mathrm{~kg} \\
\text { backpack. }\end{array}$ & $\begin{array}{l}\text { What it would be like to } \\
\text { wear/carry this through forest or } \\
\text { climb mountain? What } \\
\text { preparations need to be made } \\
\text { for a quest? How does it feel to } \\
\text { be on this quest? What are your } \\
\text { initial reactions to those } \\
\text { accompanying you? }\end{array}$ & $\begin{array}{l}\text { Characterisati } \\
\text { on }\end{array}$ \\
\hline $\begin{array}{l}\text { 2.Field of } \\
\text { Doom (St } \\
\text { Andrews } \\
\text { Corner) }\end{array}$ & $\begin{array}{l}\text { Play Minefield game blindfolded on upper lawn. Setting } \\
\text { looks beautiful, but is dangerous. Why? How would it } \\
\text { feel at night on the quest or when entering areas where } \\
\text { visibility is limited? } \\
\text { http://www.wilderdom.com/games/descriptions/Minefiel } \\
\text { d.html }\end{array}$ & $\begin{array}{l}\text { Relationships/teamwork/trust/rel } \\
\text { ying on others, danger, feelings? }\end{array}$ & $\begin{array}{l}\text { Develop } \\
\text { characterisatio } \\
\mathrm{n} \text { and setting }\end{array}$ \\
\hline $\begin{array}{l}\text { 3.Stone } \\
\text { Table } \\
\text { (Walkway) }\end{array}$ & $\begin{array}{l}\text { Smell different foods to detect which ones have been } \\
\text { 'poisoned' - survival, significant place for council, } \\
\text { sorceress, meeting, tribal gathering, eat different foods } \\
\text { even if disgusting, dancing? campfire? Challenge - } \\
\text { Solve a riddle to determine which foods are } \\
\text { acceptable/correct - rest are poisonous. YouTube clip } \\
\text { from Lord of the Rings - Gollum and Bilbo tell riddles to } \\
\text { each other }\end{array}$ & $\begin{array}{l}\text { What happens here? Comment } \\
\text { on the tension and drama }\end{array}$ & $\begin{array}{l}\text { Develop the } \\
\text { plot }\end{array}$ \\
\hline $\begin{array}{l}\text { 4.Epic } \\
\text { Citadel } \\
\text { (Under } \\
\text { Walkway) }\end{array}$ & $\begin{array}{l}\text { Sit beside beautiful stone wall /cobblestones under } \\
\text { walkway to CC Place and explore Epic Citadel app }\end{array}$ & $\begin{array}{l}\text { What is this place? Why are you } \\
\text { here? Who lives here? What } \\
\text { does it feel like/look like? } \\
\text { Friendly or eerie? }\end{array}$ & $\begin{array}{l}\text { Develop the } \\
\text { setting }\end{array}$ \\
\hline $\begin{array}{l}\text { 5.Cursed } \\
\text { Quicksand } \\
\text { (Lake } \\
\text { Precinct) }\end{array}$ & $\begin{array}{l}\text { Play Hot Chocolate River game on lake lawn. The team } \\
\text { has to cross a swamp of quicksand on magic lilly pads - } \\
\text { will only float if you're touching them, otherwise they } \\
\text { will } \\
\text { disappear.http://www.ultimatecampresource.com/site/c } \\
\text { amp-activity/hot-chocolate-river.html }\end{array}$ & $\begin{array}{l}\text { Reflect on strategies being used } \\
\text { to develop teamwork }\end{array}$ & $\begin{array}{l}\text { Develop the } \\
\text { plot }\end{array}$ \\
\hline $\begin{array}{l}\text { 6.Fiendish } \\
\text { Forest } \\
\text { (Fern } \\
\text { Gully) }\end{array}$ & $\begin{array}{l}\text { Be ready to fight off monsters - listen blindfolded to } \\
\text { sounds of dragons roaring, clash of weapons in battle, } \\
\text { owls hooting, horses snuffling, boots squelching, wind } \\
\text { whistling/sighing, wolf howling, woman screaming, } \\
\text { rats scratching, heavy footsteps, heavy breathing } \\
\text { http://myths.e2bn.org/create/tool267-sound-gallery.html } \\
\text { Listen to excerpt from Matthew Reilly's book The Great } \\
\text { Zoo of China where dragons are attacking the cable } \\
\text { car. }\end{array}$ & $\begin{array}{l}\text { What does your story sound } \\
\text { like? } \\
\text { Describe what happens when } \\
\text { the monsters attack. What } \\
\text { emotions are depicted by the } \\
\text { noises around you? }\end{array}$ & $\begin{array}{l}\text { Develop } \\
\text { descriptive } \\
\text { writing }\end{array}$ \\
\hline $\begin{array}{l}\text { 7.Eerie } \\
\text { Escarpme } \\
\text { nt } \\
\text { (Lookout) }\end{array}$ & $\begin{array}{l}\text { Need to escape a dangerous situation e.g. attack or } \\
\text { threat. Problem-solving using individual special powers. } \\
\text { Only way to move ahead in the journey is to go down } \\
\text { (YouTube- Cliffs of Insanity from The Princess Bride). } \\
\text { Dragons adventure world explorer app/ How to train } \\
\text { your dragon app/ School of dragons app/ Anomaly } \\
\text { book app Fly a dragon http://video.sfgate.com/Dragon- } \\
\text { Adventure-game-explores-augmented-reality-26413938 } \\
\text { Train a dragon https://itunes.apple.com/au/app/school- } \\
\text { dragons-how-to-train/id622944658?mt=8 and }\end{array}$ & $\begin{array}{l}\text { How do your special powers and } \\
\text { those of the group help you in } \\
\text { this situation? }\end{array}$ & $\begin{array}{l}\text { Develop plot } \\
\text { and } \\
\text { characterisatio } \\
\mathrm{n}\end{array}$ \\
\hline $\begin{array}{l}\text { Tunnel of } \\
\text { Terror } \\
\text { (Spider } \\
\text { Webs) }\end{array}$ & $\begin{array}{l}\text { Use the Real Scary Spiders app - augmented reality } \\
\text { spiders. Imagine this as any type of monster, } \\
\text { something that creeps up on you unawares, could } \\
\text { attack you at any moment. }\end{array}$ & $\begin{array}{l}\text { How will your team conquer the } \\
\text { monster? What emotions do you } \\
\text { feel? }\end{array}$ & $\begin{array}{l}\text { Develop } \\
\text { setting and } \\
\text { characterisatio } \\
\mathrm{n}\end{array}$ \\
\hline $\begin{array}{l}\text { Blazing } \\
\text { Battlefield } \\
\text { (Celebratio } \\
\mathrm{n} \text { Lawn) }\end{array}$ & $\begin{array}{l}\text { The entire group must band together to defeat a } \\
\text { fearsome evil. Play poison ball/dodgeball game as an } \\
\text { entire group } \\
\text { http://www.teachingideas.co.uk/pe/dodgeball.htm }\end{array}$ & $\begin{array}{l}\text { How did everyone work } \\
\text { together? How did you feel trying } \\
\text { to dodge the poison balls? }\end{array}$ & $\begin{array}{l}\text { Develop } \\
\text { characterizatio } \\
\mathrm{n} \text { and plot }\end{array}$ \\
\hline
\end{tabular}

Table 2: Activities and Journal Entries 